International Journal of STEM Education for Sustainability, Vol 2, No.1, 2022, pp. 94-104

e-ISSN 2798-5091. DOI. 10.53889/ijses.v2i1.53

\title{
Natural Product Chemistry (NPC) Laboratory Activity in Indonesia
}

Submitted 2 January 2022 Revised 28 January 2022 Accepted 28 January 2022

\author{
Aliefman Hakim ${ }^{1 *}$, Abdul Wahab Jufri ${ }^{2}$, Jamaluddin Jamaluddin ${ }^{3}$, Muhammad Eka Putra Ramandha ${ }^{4}$ \\ ${ }^{1}$ Chemistry Education Program, Faculty of Teacher Training and Education, \\ Universitas Mataram, Mataram, Indonesia \\ ${ }^{2,3}$ Biology Education Program, Faculty of Teacher Training and Education, \\ Universitas Mataram, Mataram, Indonesia \\ ${ }^{4}$ Pharmacy Program, Faculty of Health, Universitas Bumigora, Mataram, Indonesia \\ Corresponding email: *aliefman@unram.ac.id
}

\begin{abstract}
The purpose of this research is to integrate to provide design recommendations for the implementation of good natural product chemistry (NPC) laboratory activity. This study was used systematic review which consists of data presentation, data reduction, and drawing conclusions. The data sources come from several articles. The data are: (1) data on natural product chemistry (NPC) laboratory activity methods, (2) data on the validity of the natural product chemistry (NPC) laboratory activity module, (3) data on the effectiveness of the natural product chemistry (NPC) laboratory activity module method data. Module validity was analyzed using the aiken index. The results of the analysis show that the implementation of the natural materials practicum will be carried out if it meets several requirements, namely (1) practicum design (2) practicum module. The validity results show that the natural materials chemistry practicum module is very feasible and practical to use.
\end{abstract}

Keywords: Natural product chemistry (NPC) laboratory activity, Practicum design, Aiken index, Validity

\section{INTRODUCTION}

Natural Product Chemistry (NPC) is the most important part of organic chemistry which studies various types of compounds from organic sources, both plants, animals, and microorganisms. The objective of the Natural Product Chemistry (NPC) course is that students are able to understand the process of organic compounds occurring in living things, especially secondary metabolite compounds and understand their structural framework, chemical properties, and biological activities. These natural compounds are classified as secondary metabolites derived from primary metabolites. In the development of chemistry of natural materials, it is mainly focused on the formation of structures and investigating the properties of secondary metabolites such as terpenoids, polyketides, flavonoids, steroids, and alkaloids, separating, purifying, and finally analyzing compounds produced from living cells, as well as determine the molecular structure of the resulting compounds. The molecular structures of these compounds vary widely. Chemical compounds of natural materials have certain patterns, regularity in terms of organic chemistry, from certain groups of natural material compounds can be used to develop a directed, systematic, and logical thinking pattern. (Wasia, N. H, et al 2017). 
International Journal of STEM Education for Sustainability, Vol 2, No.1, 2022, pp. 94-104

e-ISSN 2798-5091. DOI. 10.53889/ijses.v2i1.53

Learning the Natural Product Chemistry (NPC) must be accompanied by practicum. The process of practicum activities carried out certainly aims to give students direct experience in the isolation of chemical compounds, so that they can improve mastery of concepts, problem-solving abilities and scientific skills, understand how science and scientists work, foster interest and motivation and train thinking skills. The process of isolating chemical compounds, especially secondary metabolites, requires guidance in the activity of isolating secondary metabolites. One form of practical activity guide that is commonly used is a module.

Natural Product Chemistry (NPC) Laboratory Activity that are usually carried out are separating secondary metabolites from natural materials. Secondary metabolite compounds in the form of small molecules, are specific, meaning that not all organisms contain similar compounds, have varied structures and each compound has a different function/role. Secondary metabolite compounds can be separated from natural materials through an isolation process consisting of extraction, fractionation, purification and identification (Maheasy, et al., 2018). Isolation is the process of separating a desired chemical component from other components that are contaminants in a material. Isolation of natural materials generally refers to secondary metabolites. Secondary metabolites are produced by organisms, which are compounds with low molecular weight and in small amounts. The role of secondary metabolites is as a supporting component, such as those used to defend themselves from enemies and hormones, and not the main components such as growth and reproduction (Nugroho, et al., 2017).

Modules in general can be interpreted as the smallest learning program unit that students can learn individually (self-instructional), after completing one unit in the module, students can then move forward and study the next module unit (Nuralamsyah, et al., 2017). Prastowo (2014) states that the module has several advantages, namely, a) focusing on students' thinking skills, because in essence they have the ability to work alone and must be more responsible for their actions; $b$ ) the existence of control on student learning outcomes through basic competencies that must be achieved by students.

Based on the results of observations, the natural materials chemistry practicum is applied with project-based practicum activities. Project-based practicum activities are carried out by providing opportunities for students to complete practicum activities on their own, but still under the guidance of the supporting lecturer. Learning using modules is an independent learning approach that focuses on mastering competencies according to their conditions and potential. The role of the module for students is very large in achieving learning objectives, both independent 
International Journal of STEM Education for Sustainability, Vol 2, No.1, 2022, pp. 94-104

e-ISSN 2798-5091. DOI. 10.53889/ijses.v2i1.53

learning and group learning. The use of media and learning resources is part of the components that affect learning. Current learning activities emphasize process skills and active learning, so learning media are becoming increasingly important (Tejo. 2011: 20) in Sutanto (2017:1). Modules can facilitate students in independent or conventional or group learning. Based on the case the purpose of this study is to identify and provide recommendations for good Natural Product Chemistry (NPC) Laboratory Activity Processes.

\section{METHOD}

This study was used systematic review which consists of data presentation, data reduction, and drawing conclusions. The data sources come from several articles consisting of display data, data reduction, and conclusion. Sources of data come from several articles regarding the design of Natural Product Chemistry (NPC) Laboratory Activity, module validity and effectiveness of practicum modules.

\section{RESULTS AND DISCUSSION}

Natural Product Chemistry (NPC) Laboratory Activity is the basis of work or experiments on sample preparation, extraction, purification and identification using a spectrophotometer. Sample preparation is an activity in preparing all kinds of materials and tools for practicum. In particular, the main ingredients to be analyzed are samples of natural materials. The determination of natural materials to be used in experiments must meet the criteria of being attractive, useful, and most importantly, no previous research has been conducted on these natural materials. For example, most of the Indonesian people, especially those who live in villages, still use plants as medicine or are used as treatment, this is done because of ancestral stories or past history. Cases like this can be used as the basis for conducting chemical experiments on natural materials, by testing plants that are believed to be able to cure them. Interesting and novel aspects will be fulfilled if you follow this line of thinking.

In order to obtain sufficient amounts of pure secondary metabolites for determination of the total structure, approximately $0.5-2 \mathrm{~kg}$ of dry plant matter is required. For some plants, the season in which they are collected regulates to a large extent the nature and amount of metabolites present in the stems or leaves. The best method for collecting plant material is freezing in the field using solid $\mathrm{CO}_{2}$ or liquid $\mathrm{N}_{2}$. The frozen plant material can then be stored frozen or subsequently freezedried. Alternatively, the plant can be carefully dried in the shade (drying in the sun can cause photodegradation of the constituents). Prior to extraction, plant material should be macerated if 
fresh or frozen, or ground if dried. If the sample is small or the plant material is fresh or frozen, a pestle and mortar will suffice; otherwise, a blender, mechanical grinder, or grinder is working fine.

We have developed a scheme to obtain three extracts different polarity. A small initial recovery is sufficient. To obtain sufficient extracts for in vivo experiments dry, ground Plant material $(5 \mathrm{~g})$ is covered with 2 volumes of methylene. Chloride was added and stirred for 20 minutes filter the solvent, repeat extraction and recover collected solvent to dry. Initial extraction if plant material is fresh or frozen a methylene chloride/methanol mixture (50/50) and Subsequent extractions are performed as described. Repeat this process using methanol as solvent. Methanol extract is added to the methylene residue. Chloride extraction and extraction of the resulting solution 3 times the same volume of hexane (smaller amount of water may be required to promote phase separation). Steps are separated and combined. After solvent removal, the hexane and methanol phases give non-polar and polar organic extracts, respectively. In most cases, the local use of these plants for medicinal purposes involves: Water extraction or poultice, hot water extract $\left(90^{\circ} \mathrm{C}\right)$ can be prepared from the extracted plant material or from a fresh sample providing a third (aqueous) extract if preferred. Neutral water can be used in most cases, although local ethnobotanical procedures may involve acidic or basic conditions.

Large-scale extraction of plant material is initiated based on the properties of the original extract to exhibit bioactivity. Choose a suitable extraction solvent and extract $500 \mathrm{~g}$ plant samples three times with 2 volumes of solvent. Remove the solvent (a rotary evaporator can be used. Here), the resulting crude extract is tested to confirm its biological activity. The crude extract is often analyzed by TLC, and based on the results, a silica gel column is often run to subfraction the crude extract. Then, the bioactivity of the sub-fraction is checked and the active sub-fraction is selected for further purification. The active compounds are usually obtained in pure form after further chromatographic steps. If the compound is in the correct polarity range, silica gel chromatography works satisfactorily. Where possible, preparative and analytical HPLC is very useful for separating mixtures and determining the purity of isolated compounds.

After obtaining the pure chemical composition, the first step to clarifying the structure is to determine: its molecular weight. For high-resolution mass spectrometers (HRMS), accurate mass measurement the parent ion often represents the most probable molecule method. Many pure natural products, especially glycosides and related compounds, fast atomic bombardment (FAB) Although the mass spectrometry method of choice for analysis More volatile compounds of electron impact (EI) and chemicals Ionization (CI) can provide useful data mass spectrometry in 
many cases the pattern of spectral fragmentation is Molecular formulas of major decay fragments, this is useful for defining the overall structure tandem Methods such as GC-MS or HPLC-MS are Simultaneous disconnection and identification of connections interest. Electrospray MS technology is useful for compounds. With a molar mass of about 1000 or more. The most useful way to determine the structure However, natural products are X-ray diffraction and NMR spectroscopy. If the quality is good, the first method is preferred. If you can get crystals and have access V appropriate equipment. C 1D and 2D NMR Experiments are usually sufficient to obtain small structures. Molecules (up to 1000 MW). (Walsh, E. L et al 2012)

Quantitative experiments ${ }^{1} \mathrm{H}$ and ${ }^{1313} \mathrm{C}$ gives the total number of carbon atoms in a compound. These data combined with high-resolution mass spectral data; usually sufficient to obtain the molecular formula unknown connection. Most natural products are mined. Plants are made up only of carbon, hydrogen and oxygen. Excluding some classes' nitrogen compounds such as alkaloids. NMR Department Experiment define everything quaternary carbon atom Well, how about them? Connected one, two or three hydrogen atom. 2D NMR Experiment, COSY and heckor, show connection Neighborhood hydrogen atom and hydrogen atom to carbon atom each. Sometimes more complex Experiment Such as NOESY, HMBC or inappropriate is necessary sugar saturated Definition of structure. However, these technicians Often it can only be used in welltrained laboratories. Spectrometer operator.

Based on the results of the literature review, a good practicum will be carried out if the practicum is prepared seriously. This can be done by designing a chemistry practicum of natural materials. The following are recommendations for the design of natural materials chemistry practicums:

\section{Opening Phase}

In this opening phase, lecturers and students will carry out several activities as follows:

a. The lecturer provides an explanation of the practicum and the practicum scheme that will be carried out.

b. Prerequisites for the test (a diagnostic test to establish basic knowledge of chromatography and spectroscopy techniques. For example, students understand how to interpret, Uv-Vis, Infra-Red, AAS, NMR spectra.)

c. Pre-test. 
This process is carried out to determine student understanding of the practicum that will be carried out. It is also used to assess students' understanding of the chemical theories of natural materials that have been taught.

\section{Laboratory training Phase}

a. Group composition (3-4 people per group) according to preliminary and preliminary test results.

b. Instructor discussed the concept with a high percentage of incorrect answers in the prerequisites. Students practicing in groups Isolation of secondary metabolites

c. Instructor and teaching assistant explained to students the procedure for isolating secondary metabolites.

3. Orientation problem Phase

a. Students are given an assignment.

b. Each group worked on one plant sample.

c. Your instructor will tell you about the mini design lab you will be running.

4. Designing laboratory activities Phase

a. Students reviewed literature from various sources and suggested projects.

b. The teacher acted as a facilitator, giving the students time to answer questions

5. Presenting laboratory activities proposal Phase

a. Students pass their proposals to another group. Communication was conducted through presentations.

b. Another group of students was informed about the procedure for isolating secondary metabolites from studied plant samples. We provide some questions or suggestions for suggestions for improvement. Instructors acted as facilitators in solving various problems. It happened during a class discussion.

6. Implementation of laboratory activities Phase

a. Students implemented the proposal and collected data on sample preparation, extraction, classification, and purification structure. Description of secondary metabolites.

b. In addition to directing the investigation, the instructor acted as a facilitator.

7. Results reporting and presentation Phase

a. Students have submitted their research report.

b. Students shared project reports with other groups. Communication took place through presentations. 
c. The other group of students received the information and made some questions or suggestions for the project report improvement. Instructors acted as facilitators of various issues that arose during class discussions.

\section{8. laboratory evaluation Activities and Analytics complex concept Phase}

a. The students appreciated the completed laboratory work. Laboratory performance evaluation performed by evaluation Providing in-house procedures and corrective solutions.

b. Students draw conclusions about complex concepts based on information obtained during lab activities, such as in secondary school. Nomenclature of metabolites, general characteristics of secondary metabolites, structural characteristics of secondary metabolites, Separation and identification of chemical components. The cation of the secondary structure of the metabolite.

c. Post-test

After the practicum design is carried out, the next important step in planning the natural materials chemistry practicum is the practicum module. The practicum module is important because the module is a student guide in doing practicum. The content of the module must be clear and straightforward. The purpose of being clear and straightforward is that the guiding sentences in the module must use standard sentences and are adapted to the Enhanced Spelling. A good module will produce a good validity value after testing by experts. The following is data for several practicum modules:

Table. 1. Data Aiken Index Value and Practical of Lot of Module

\begin{tabular}{|c|c|c|c|}
\hline No & Aiken Index Value & Practical Value & Result \\
\hline 1 & $\mathrm{~V}=0.90$ & $89 \%$ & $\begin{array}{l}\text { The natural ingredients chemistry practicum } \\
\text { module on the isolation of quercetin-3-O- } \\
\text { glycoside (routine) from rubber yam leaves } \\
\text { developed through a 4D model is very feasible } \\
\text { and practical so that it can be used }\end{array}$ \\
\hline 2 & $\mathrm{~V}=0.82$ & $84 \%$ & $\begin{array}{l}\text { The natural ingredients chemistry practicum } \\
\text { module on cinnamaldehyde isolation from } \\
\text { cinnamon is feasible and practical so that it can } \\
\text { be used }\end{array}$ \\
\hline 3 & $\mathrm{~V}=0.70$ & $80 \%$ & $\begin{array}{l}\text { Natural ingredients chemistry practicum module } \\
\text { on trimyristin isolation from nutmeg, feasible } \\
\text { and practical, so it can be used }\end{array}$ \\
\hline 4 & $\mathrm{~V}=0.79$ & $82 \%$ & $\begin{array}{l}\text { The natural ingredients chemistry practicum } \\
\text { module on the isolation of stigmasterol } \\
\text { compounds from the leaves of the majapahit }\end{array}$ \\
\hline
\end{tabular}




\begin{tabular}{cccl}
\hline No & Aiken Index Value & Practical Value & \multicolumn{1}{c}{ Result } \\
\hline 5 & $\mathrm{~V}=0.89$ & $85 \%$ & $\begin{array}{l}\text { plant, is feasible and practical, so that it can be } \\
\text { used } \\
\text { The chemical supplement book of natural } \\
\text { ingredients on the phytochemical screening } \\
\text { material of the genus Premna is very feasible } \\
\text { The generic science-based natural ingredients } \\
\text { chemistry practicum module on the isolation of } \\
\text { caffeine from coffee grounds is feasible and pr } \\
\text { actical so that it can be used. } \\
\text { Generic science-based chemistry practicum } \\
\text { module on isolation of pectin from banana peels, } \\
\text { feasible and practical so that it can be used in } \\
\text { learning } \\
\text { Natural materials chemistry practicum module } \\
\text { on the isolation of triterpenoid lupeol from } \\
\text { mangrove leaves, feasible and practical, so it can } \\
\text { be used } \\
\text { The natural ingredients chemistry practicum } \\
\text { module on the isolation of anacardic acid } \\
\text { compounds from cashew seed shells is feasible } \\
\text { and practical, so it can be used } \\
\text { Natural materials chemistry practicum module } \\
\text { on computational-based corrosion inhibition } \\
\text { tests for natural compounds derived from purine } \\
\text { compounds }\end{array}$ \\
\hline $\mathrm{V}=0.74$ & $85 \%$ & $78 \%$ \\
\hline
\end{tabular}

Based on the results of these data, the natural materials chemistry practicum modules have been feasible and can be used. Each module has compounds that are analyzed differently. This shows how wide the scope of natural materials chemistry courses is. The validity of aiken is in the high to very high range, this fact makes the modules that have been created or developed can be implemented or applied to natural materials chemistry labs.

The practicality value is the value of the module validity test results from the experts. This expert validity test is in the form of a content validity test, which is a validity that checks the compatibility between test items made with indicators, materials or learning objectives that have been set. Content validity can only be determined based on the judgment from experts and practicality. This study aims to produce a product in the form of a valid and practical practicum module to be used in the learning process. At this stage the initial product (prototype 1) produced is tested for validity with a validity test to get constructive input and suggestions so that the practicum module developed is better and suitable for use as a practicum medium. The validity test 
uses an instrument in the form of an expert validation sheet that contains a graphic component, a presentation component, a content feasibility component and a linguistic component. The research instrument is certainly related to validity and reliability. The analysis used in determining the level of module validity is the Aiken index where the validity is carried out on two validators. (Zakirman dan Hidayati. 2017)

Research result Hakim, et al (2020) shows that the average value of the natural material chemistry practicum of students who are provided with a practicum module is 82.4 with a KKM of 75. This gives the fact that natural material chemistry if studied with practicum and assisted by a good practicum module will make student learning outcomes or grades better also. Other studies give the impression that the chemistry of natural materials should be taught using the project or practical method. (Judge)

\section{CONCLUSION}

Natural Product Chemistry (NPC) Laboratory Activity will go according to plan, if it is carried out with planning in the form of a good practicum design. In addition to practicum design, supporting modules are also important, so that students can do practicum according to procedures and in a structured way.

\section{REFERENCES}

Adawiyah, S. R., Hakim, A., \& Hadisaputra, S. (2020). Pengembangan Modul Praktikum Kimia Bahan Alam Berbasis Generik Sains: Isolasi Fenobarbiton dari Kulit Batang Pohon Api-api (Avicennia marina). Chemistry Education Practice, 3(2), 84-90.

Boonphong, S., Baramee, A., Kittakoop, P., \& Puangsombat, P. (2007). Antitubercular and antiplasmodial prenylated flavones from the roots of Artocarpus altilis. Chiang Mai J Sci, 34(3), 339-344.

Carroll, A. M., Kavanagh, D. J., McGovern, F. P., Reilly, J. W., \& Walsh, J. J. (2012). Nature's Chiral Catalyst and Anti-Malarial Agent: Isolation and Structure Elucidation of Cinchonine and Quinine from Cinchona calisaya. Journal of Chemical Education, 89(12), 1578-1581.

Hajar, S., Junaidi, E., \& Hakim, A. (2020). Pengembangan Modul Praktikum Isolasi Senyawa Dari Daun Ubi Karet Sebagai Penunjang Perkuliahan Kimia Bahan Alam. Chemistry Education Practice, 3(1), 23-28.

Halpin, C. M., Reilly, C., \& Walsh, J. J. (2010). Nature's anti-alzheimer's drug: Isolation and structure elucidation of galantamine from Leucojum aestivum. Journal of chemical education, 87(11), 1242-1243. 
Hake, R. R. (1998). Interactive-engagement versus traditional methods: A six-thousand-student survey of mechanics test data for introductory physics courses. American journal of Physics, 66(1), 64-74.

Hakim, A., Kadarohman, A., \& Syah, Y. M. (2016). Making a natural product chemistry course meaningful with a mini project laboratory. Journal of Chemical Education, 93(1), 193196.

Hakim, A., Jufri, A. W., Jamaluddin, Supriadi, \& Mutmainnah, P. A. (2020). Understanding the Uniqueness of Artocarpus Flavonoids: Isolation and Structure Elucidation of Cycloartocarpin from the Roots of Artocarpus altilis. Journal of Chemical Education, 97(11), 4133-4136.

Muliani, S., Hakim, A., \& Al Idrus, S. W. (2021). Pengembangan Modul Praktikum Kimia Bahan Alam: Isolasi Senyawa Stigmasterrol dari Daun Tumbuhan Majapahit (Crescentia cujete). Chemistry Education Practice, 4(3), 224-230.

Musthapa, I., Hakim, E. H., Syah, Y. M., \& Juliawaty, L. D. (2016). Cytotoxic activities of prenylated flavonoids from Artocarpus heterophyllus. Journal of Engineering and Applied Sciences, 11(16), 9754-9758.

Nair, P. M., Rao, A. R., \& Venkataraman, K. (1964). Cycloartocarpin. Tetrahedron Letters, 5(2), 125-128.

Mohd Nazri, M., Samat, F. D., Kavanagh, P. V., \& Walsh, J. J. (2012). Nature's cholesterollowering drug: Isolation and structure elucidation of lovastatin from Red Yeast RiceContaining dietary supplements. Journal of Chemical Education, 89(1), 138-140.

Nguyen, M. T., Le, T. H., Nguyen, H. X., Dang, P. H., Do, T. N., Abe, M., ... \& Nguyen, N. T. (2017). Artocarmins G-M, prenylated 4-chromenones from the stems of Artocarpus rigida and their tyrosinase inhibitory activities. Journal of natural products, 80(12), 3172-3178.

Nugroho, E.B.P., Budiasih E, dan Sukarianingsih D. (2017). Pengembangan Buku Petunjuk Praktikum Kimia SMA/MA Kelas X Semester 2 Berbasis Learning Cycle. Jurnal Inovasi Terknologi Pendidikan. 4 (1),817-813.

Nuralamsyah, N., \& Rosmiati, R. (2017). Pembuatan Modul Berbasis Komputer pada Mata Kuliah Praktek Dasar dan Pengukuran Listrikteknik Elektronika Universitas Negeri Makassar. ILTEK: Jurnal Teknologi, 12(01), 1706-1712.

Prastowo, A. (2011). Panduan kreatif membuat bahan ajar inovatif. Yogyakarta: Diva Press. 
Sari, A., Savalas, L. R. T., \& Hakim, A. (2020). Pengembangan Modul Praktikum Kimia Bahan Alam Tentang Isolasi Senyawa Dari Minyak Kayu Manis. Chemistry Education Practice, 3(1), 12-16.

Sutanto, P. (2017). Panduan Praktis Penyusunan e-Modul. Jakarta: Direktur Pembinaan SMA, Depdiknas.

Wahyuono, S. (1993). Identifikasi lupeol, asetil lupeol dan lupeil t3-hidroksioktadekanoat yang terdapat di dalam fraksi non-polar amsonia grandiflora (fam. Apocynaceae). Majalah Farmasi Indonesia, 4(1993).

Walsh, E. L., Ashe, S., \& Walsh, J. J. (2012). Nature's Migraine Treatment: Isolation and Structure Elucidation of Parthenolide from Tanacetum parthenium. Journal of Chemical Education, 89(1), 134-137.

Wasia, N. H., Sudarma, I. M., Savalas, L. R. T., \& Hakim, A. (2017). ISOLASI SENYAWA SINAMALDEHID DARI BATANG KAYU MANIS (Cinnamomum burmanii) DENGAN METODE KROMATOGRAFI KOLOM. Jurnal Pijar Mipa, 12(2), 91-94.

Zakirman, Z., \& Hidayati, H. (2017). Praktikalitas Media Video dan Animasi dalam Pembelajaran Fisika di SMP. Jurnal Ilmiah Pendidikan Fisika Al-Biruni, 6(1), 85-93. 